\title{
Heritability of growth traits in a natural population of the facultative apomictic tree Aspidosperma polyneuron
}

\author{
Herdabilidade de caracteres de crescimento em uma população \\ natural da árvore apomítica facultativa, Aspidosperma polyneuron
}

\author{
Camila Lucas Chaves ${ }^{1 *}$, Alexandre Magno Sebbenn ${ }^{2}$, Adrivanio Baranoski ${ }^{3}$, \\ Bruna Delgado Góes ${ }^{3}$ and Paulo Maurício Ruas ${ }^{3}$
}

\begin{abstract}
Resumo
Conhecer a herdabilidade de caracteres de crescimento é importante nas populações naturais por indicar a capacidade que a seleção natural e artificial tem para mudar a média de populações. Neste trabalho foram estimados a herdabilidade para altura total $(\mathrm{H})$ e diâmetro ao nível do colo (RCD), de juvenis de Aspidosperma polyneuron em duas parcelas (P1, P2) estabelecidas em uma população natural, usando locos microssatélites. A herdabilidade foi calculada por regressão da diferença entre pares entre o total de amostras e os juvenis apomíticos excluídos de seus pares de parentais. A análise indicou que a herdabilidade baseada em toda a amostra (RCD: $\mathrm{P} 1=0,266, \mathrm{P} 2=0,086 ; \mathrm{H}: \mathrm{P} 1=0,168, \mathrm{P} 2=0,042$ ) foi similar para sem apomíticos (RCD: P1 = 0,264, P2 = 0,087; H: P1 = 0,170, P2 = 0,050). No entanto, em geral, os apomíticos mostraram o melhor desempenho, alcançando maior RCD e H. Assim, a seleção natura e artificial de indivíduos apomíticos e uma opção para regeneração da população, visto que os apomíticos são adaptados ao ambiente de estudo.
\end{abstract}

Palavras-chave: Locos microssatélites, melhoramento in situ, seleção natural, melhoramento florestal, árvores tropicais.

\begin{abstract}
Understanding the heritability of growth traits is important in natural populations because it indicates the capacity of natural and artificial selection to alter the average traits in a population. Here, we use microsatellite loci to estimate heritability for total height $(\mathrm{H})$ and root collar diameter (RCD), in juveniles of Aspidosperma polyneuron in two plots (P1, P2) established in a natural population. Heritability was calculated by regression for pairwise differences in traits for the total sample, and only for non-apomictic juveniles. The analysis indicates that heritability based on the entire sample (RCD: $\mathrm{P} 1=0.266, \mathrm{P} 2=0.086 ; \mathrm{H}: \mathrm{P} 1=0.168, \mathrm{P} 2=0.042$ ) was similar to the sample excluding apomicts (RCD: $\mathrm{P} 1=0.264, \mathrm{P} 2=0.087 ; \mathrm{H}: \mathrm{P} 1=0.170, \mathrm{P} 2=0.050$ ). However, apomicts generally show better performance, reaching greater RCD and $\mathrm{H}$ than non-apomicts. Thus, the natural and artificial selection of apomict individuals are options for population regeneration since they are well adapted to the study environment.
\end{abstract}

Keywords: Microsatellite loci, in situ breeding, natural selection, forest improvement, tropical tree.

\section{INTRODUCTION}

Aspidosperma polyneuron Müll. Arg. is a Neotropical tree with significant economic and ecological value (CHAVES et al., 2017). Due to the high quality of its timber, the species was exploited extensively in the past and as a consequence it is currently classified as in danger of extinction on the IUCN Red List of Threatened Species (Version 2015-4). Species with high economic and ecological value such as A. polyneuron increase the biological value of forests, particularly considering environmental reforestation and tree improvement programs (DEMESURE et al., 2000). The range of the species occurs across Brazil, Argentina, Bolivia, Colombia, Paraguay, Peru, and Venezuela. As an emerging

1. Department of Forest Sciences, Escola Superior de Agricultura "Luiz de Queiroz" - ESALQ, Universidade de São Paulo - USP. Piracicaba / SP, Brazil. *Corresponding author: kmila2252@yahoo.com.br

2. Instituto Florestal de São Paulo - IF. São Paulo / SP, Brazil.

3. Universidade Estadual de Londrina - UEL. Londrina / PR, Brazil. 
species that occupies the forest canopy, it can reach up to $50 \mathrm{~m}$ in height, $390 \mathrm{~cm}$ in diameter at breast height (dbh), and live for up to 1200 years (CARVALHO, 2003). Reproductive maturity begins between 20 to 30 years of age, when tree height is greater than $8.6 \mathrm{~m}$ and dbh larger than $10 \mathrm{~cm}$ (CARVALHO, 2003). Seeds produce excess embryos due to polyembryony (RIBAS et al., 2017) and the species presents facultative apomixis (CHAVES et al., 2017). Apomixis generates descendants that are genetically identical to their mother (clones), as seeds originate from embryos derived exclusively from cells of maternal ovule tissues (KOLTUNOW et al., 1995). This process ensures the survival of many genotypes that are vigorous and well adapted to the area surrounding the mother (CHAVES et al., 2017).

Tree improvement programs are based on the selection of the best genotypes as parents of subsequent improved generations, resulting in genetic gains such as increased growth rate, adaptation, timber quality, and resistance to disease and pests (RESENDE, 2002). Success in selection depends on genetic variability, control of the traits of interest (heritability coefficient), and selection intensity (RESENDE, 2002). High genetic variability, heritability, and selection intensity will result in increased genetic gains (RESENDE, 2002; SILVA et al., 2015a, b).

In general, heritability is estimated from progeny tests, developed using open-pollinated or hand pollinated seedlings, planted in experimental trials with a controlled environment (i.e., homogeneous soil, spacing, luminosity, altitude). The heritability of economic growth traits may also be estimated in natural populations if genetic markers are used to reconstruct relatedness among the sampled individuals (KUBOTA et al., 2015; RITLAND, 1996; SILVA et al., 2015a). This enables an understanding of the level of genetic control and offers insights into how natural and artificial selection affect these traits.

Estimates of narrow sense heritability in progeny tests, based on open-pollinated families of tree species, have generally shown low values $(<0.5)$ for economically important traits, such as height and dbh (ARAUJO et al., 2014; PAGLIARINI et al., 2016; PUPIN et al., 2015; ZARUMA et al., 2015). The magnitude of values for such estimates are obviously influenced by genetic variability of the study populations, age of individuals, environmental control of the trials, and estimation methods (RESENDE, 2002). However, studies of heritability for economic growth traits like height and dbh in natural populations are still lacking for many tree species, including for facultative apomictic trees such as A. polyneuron. Heritability in natural populations can be calculated by covariance between relatedness and phenotype similarity for quantitative traits (BESSEGA et al., 2011). Advances in molecular markers have enabled the development of techniques to estimate heritability in natural populations (MOUSSEAU et al., 1998). For example, microsatellite markers have high polymorphism in terms of number of alleles per loci and they present codominant inheritance, thus providing robust estimates of relatedness between individuals (ASHLEY; DOWN, 1994). However, estimates of heritability in natural populations is challenging, especially for tropical forest tree species which are highly complex (i.e., with unknown relatedness, individuals with different ages, and environmental heterogeneity), resulting in different degrees of relatedness and competition between individuals (MOUSSEAU et al., 1998). This complexity results in high levels of variation for phenotypic traits and relatedness between individuals. Nevertheless, tree species are sedentary and commonly have a restricted seed dispersal pattern, resulting in intra-populational spatial genetic structure (SGS) due to the establishment of regeneration near to the mother tree. This may increase genetic similarity of near-neighbor regenerants (relatedness) and their phenotypic correlation, thus favoring heritability estimates (RITLAND, 1996).

The aim of this study was to estimate heritability of growth traits in a natural population of A. polyneuron juveniles. We used microsatellite loci to determine the strength of natural selection and the potential of in situ genetic improvement. We also assessed differences between the heritability coefficient of plant height and root collar diameter and the influence of apomixis on these estimates.

\section{MATERIALS AND METHODS}

The study was carried out in the "Mata dos Godoy" conservation area $\left(23^{\circ} 27^{\prime} \mathrm{S}\right.$ and $51^{\circ} 15^{\prime} \mathrm{W}$, altitude of $700 \mathrm{~m}$ ), one of the last remnants of the Seasonal Semideciduous Atlantic Forest in Paraná

State, Brazil. It includes a legally protected area of about 681 ha that has not been subjected to selective logging or any other anthropogenic influences (TOREZAN et al., 2005). Two subplots (P1 and P2) of 
0.25 ha $(50 \times 50 \mathrm{~m})$ were established near the center of two larger plots, one of 9 ha and the other 5.06 ha. In each subplot all identified A. polyneuron juvenile individuals were mapped using GPS, and leaf tissues were sampled for DNA extraction. Total height $(\mathrm{H})$ and root collar diameter at ground level (RCD) was measured using calipers and a tape measure. Juveniles are defined as individuals that are non-reproductive or with diameter at breast height less than $10 \mathrm{~cm}$ (CARVALHO, 2003). While the larger study plots have the same history, they show some differences: P1 is a mature forest with old trees, a closed canopy, and a well-defined understory; P2 is visibly different due to the large number of lianas and clearings.

DNA extraction from juvenile samples was carried out using the protocol described by Doyle and Doyle (1990). DNA analyses were based on seven microsatellite loci (Apn20, Apn21, Apn22, Apn23, Apn24, Apn26, and Apn27) developed by Ramos et al. (2011).

The identification of apomictic juvenile individuals in each plot was conducted using the software CERVUS 3.0 (KALINOWSKI et al., 2007). All juvenile individuals were classified into H and RCD size intervals, incorporating all measured size classes, and frequency distribution was calculated for both apomictic and non-apomictic individuals. The Kolmogorov-Smirnov test was used to prove concordance between accumulated distribution for a set of samples and an expected theoretical cumulative distribution (Figure 1), using the software BioEstat 5.0 (AYRES et al., 2007). Heritability estimates were based on juvenile individuals of unknown relatedness that likely resulted from different reproductive events. Estimates were carried out between juveniles located at distances of up to $43 \mathrm{~m}$, defined based on a previous analysis of intrapopulation SGS which indicated $43 \mathrm{~m}$ as the maximum distance between related juveniles (CHAVES et al., 2017). Pairwise estimates of coancestry showing negative values were excluded from the analysis as it indicates an absence of relatedness. Heritability was estimated based on the joint measurement of phenotypic similarity for a quantitative trait of an $i$-th pair of individuals (RITLAND, 1996). Traits were transformed using z distribution. The phenotypic similarity $\left(\mathrm{Z}_{\mathrm{i}}\right)$ for trait $i$ between pairwise individuals was calculated as:
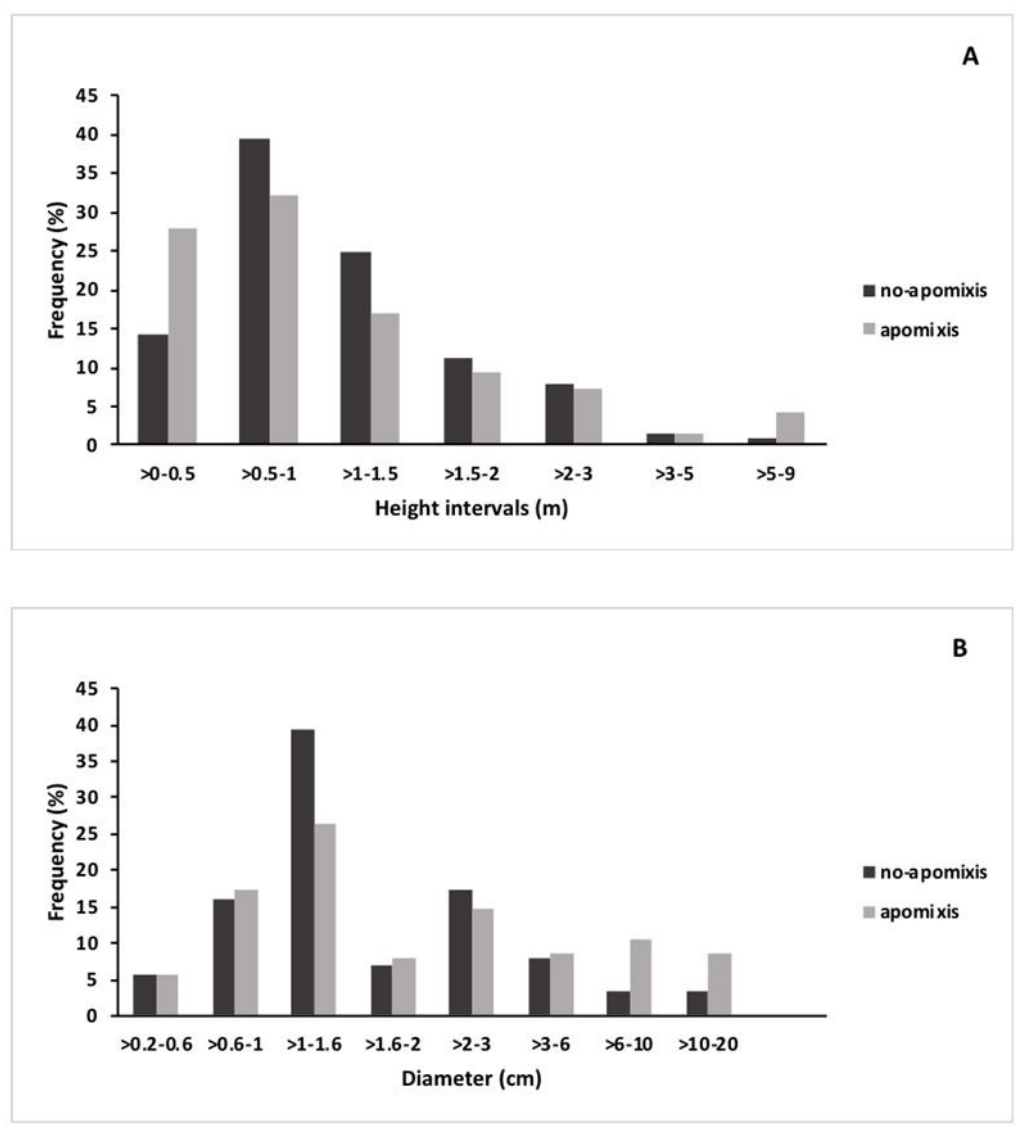

Figure 1. Frequency distribution of non-apomictic and apomictic $A$. polyneuron individuals in different class intervals for height (A) and root collar diameter at ground level (B).

Figura 1. Distribuição de frequência de não apomíticos e apomíticos de $A$. polyneuron em diferentes classes de intervalos de Altura (A) e diâmetro ao nível do solo (B). 


$$
\mathrm{Z}_{\mathrm{i}}=\frac{\left(\mathrm{Y}_{\mathrm{i}}-\mathrm{U}\right)\left(\mathrm{Y}_{\mathrm{i}}^{\prime}-\mathrm{U}\right)}{\mathrm{V}}
$$

where, $Y_{i}$ is the trait value in the first individual and $Y_{i}^{\prime}$ is the trait value in the second, and $V$ and $U$ are the sample variance and mean of the trait in the population, respectively (RITLAND, 1996). The heritability coefficient was calculated manually by regression for pairwise differences in traits between juveniles based on pairwise relatedness:

$$
\mathrm{h}^{2}=\frac{\mathrm{C}_{\mathrm{Zi}} \theta}{2 \mathrm{~V} \theta}
$$

where, $C_{\mathrm{Zi}}$ is the sample covariance between phenotypic similarity $\left(\mathrm{Z}_{\mathrm{i}}\right)$ and pairwise relatedness $(\theta$ ), and $\mathrm{v} \theta$ is the sample variance of relatedness among all pairwise individuals (RITLAND, 1996). We estimated pairwise relatedness using the coancestry coefficient $\left(\theta_{\mathrm{xy}}\right)$, as describe by Loiselle et al. (1995), with a 95\% confidence error interval by Jackknife resampling among loci, and the SPAGEDI 1.3 software (HARDY; VEKEMANS, 2002). We opted for Loiselle et al. (1995) estimator of relatedness because it does not assume Hardy-Weinberg equilibrium and the juveniles sampled in P2 present inbreeding (0.399) (CHAVES et al., 2017). As heritability estimates require that individuals are related, only pairs of individuals expected to be related were included. According to Tambarussi et al. (2017), we considered individuals to be related when coancestry was at least 0.1 .

\section{RESULTS AND DISCUSSION}

Out of the 401 and 166 juveniles sampled in P1 and P2, respectively, 129 and 120 juveniles presented distinct multilocus genotypes. This indicates that $67.8 \%$ [1-(129/401)] of the juveniles from P1 and 27.7\% [1-(120/166)] from P2 are apomicts. Apomictic reproduction and mating among unrelated apomictic individuals increase genetic diversity and fitness, favoring adaptation to the environmental conditions in which the mother tree occurs (CHAVES et al., 2017). However, individual fitness is likely site specific, and not general for all populations.

Diameter for both apomictic and non-apomictic individuals ranged from 0.2 to $17 \mathrm{~cm}$, and for related individuals used in heritability analysis it ranged from 0.2 to $4.5 \mathrm{~cm}$. The $\mathrm{H}$ for overall apomictic individuals ranged from 0.3 to $8 \mathrm{~m}$ and non-apomictic from 0.25 to $8.36 \mathrm{~m}$. However, for related individuals the $\mathrm{H}$ ranged from 0.2 to $3.5 \mathrm{~m}$. Although apomictic individuals show exceptional results in some classes, especially greater than $3 \mathrm{~m}$ in $\mathrm{H}$ and $3 \mathrm{~cm}$ RCD, most individuals originated from sexual reproduction. The frequency distribution for RCD and H (Figure 1) intervals in apomictic and non-apomictic juveniles have an asymmetric distribution curve, with the adherence test of concordance between distributions being significant $(\mathrm{P}<0.05)$, showing difference between distributions.

The mean pairwise coancestry coefficient was similar between plots (Table 1 ), suggesting that related juveniles are generally full-sibs $(\theta=0.25)$. Meanwhile, heritability for RCD and $\mathrm{H}$ were greater in P1 $(\mathrm{RCD}=0.266, \mathrm{H}=0.168)$ than $\mathrm{P} 2(\mathrm{RCD}=0.086, \mathrm{H}=0.042)$. Heritability estimates indicate that $\mathrm{RCD}$ and $\mathrm{H}$ are controlled genetically and despite a moderate heritability (ranging from 0.042 to 0.266 ), it is possible to change the population-wise mean of these traits through artificial selection. Genetic control differs extensively across growth traits in tree populations (CORNELIUS, 1994) and, in general, diameter has been detected as more heritable than height (KREMER, 1992), which is consistent with our findinds for A. polyneuron. In contrast, estimates of heritability in natural populations of the tropical tree Copaifera langsdorffii showed generally lower values for dbh (0.03-0.08) among juveniles than for $\mathrm{H}$ (0.07-0.10) (KUBOTA et al., 2015). Similar results were detected for Schizolobium parahyba, where heritability for dbh ranged from 0.01 to 0.13 and for $\mathrm{H}$ ranged from 0.01 to 0.39 (CHINELATO et al., 2014). A review of 67 studies on heritability estimates for six traits (height, diameter, volume, straightness, morphology/structure, and branching) in Pinus sp. and other conifers, Eucalyptus sp., and other tree species suggest that heritability is usually less than 0.4 and frequently ranges from 0.1 to 0.3 , and thus tends to be weak to moderate (CORNELIUS, 1994). The evidence suggests that height tends to have greater heritability than diameter, but is species specific and not a general pattern (CORNELIUS, 1994). Heritability for growth traits in A. polyneuron is an example where diameter has greater heritability than $\mathrm{H}$.

The heritability of traits for P2 showed lower values than P1. The difference between plots is likely the result of a larger number of related juvenile individuals in P1 than P2 that are adapted specifically 
Chaves et al. - Heritability of growth traits in a natural population of the

facultative apomictic tree Aspidosperma polyneuron

Table 1. Heritability coefficient estimates of $A$. polyneuron juveniles for root collar diameter (RCD) and total height (H) in plots $\mathrm{P} 1$ and $\mathrm{P} 2$.

Tabela 1. Estimativa do coeficiente de herdabilidade em juvenis de A. polyneuron para diâmetro em nível de solo (RCD) e altura total $(H)$ em parcelas (P1 e P2).

\begin{tabular}{ccccc}
\hline & NP & $\theta(95 \%$ Cl) & $\mathbf{h}_{\mathbf{A}}^{2}$ & $\mathbf{h}_{\mathbf{B}}^{2}$ \\
\hline P1: RCD & 27587 & $0.253(0.251-0.255)$ & 0.266 & 0.264 \\
P1: H & 27587 & $0.253(0.251-0.255)$ & 0.168 & 0.170 \\
P2: RCD & 4906 & $0.255(0.251-0.260)$ & 0.086 & 0.087 \\
P2: H & 4906 & $0.255(0.251-0.260)$ & 0.042 & 0.050 \\
\hline
\end{tabular}

$\mathrm{Cl}$ is the $95 \%$ confidence interval; NP is the number of pairwise individuals used for the estimates; $\theta$ is the mean coancestry coefficient; $\mathrm{h}_{\mathrm{A}}^{2}$ and $\mathrm{h}_{\mathrm{B}}^{2}$ are the heritability estimates for all individuals (apomictic and non-apomictic) and only non-apomictic individuals, respectively.

to local conditions, considering the environmental differences between the plots. The presence of lianas and clearings in P2 can influence the establishment of A. polyneuron individuals due to the fact that it is a semi-heliophile or shade tolerant species (CARVALHO, 2003). We must also consider that tree growth is the result of genetics, environmental characteristics, and the interaction between these two factors, and the impact of these factors vary for each individual. Even if individuals are from the same gene pool, environmental conditions are heterogeneous for specific genotypes, thus influencing heritability. Several non-genetic factors play a dominant role in early growth and can mask heritable differences, and usually there are a large number of unlinked genes that have a small effect on control of the growth traits (NAMKOONG, 1979). The results of the present study may also have been influenced by differences in tree age, where most juvenile individuals are in the first classes or at a young age; studies have shown that phenotypic and additive genetic variance increase with age for both diameter and height (BELTRAME et al., 2012; NAMKOONG, 1979; SEBBENN et al.; 1999a). However, we note that the opposite has been found in other studies showing a decrease in heritability with individual growth (COUTINHO et al., 2017; MASSARO et al., 2010), while others found variations across tree age for different sites and traits (MORAES et al., 2014; SEBBENN et al.; $1998,1999 b)$. Thus, tree age is not the only factor that affects levels of heritability.

We found an increase in the heritability coefficient when apomictic individuals were excluded from the analysis in both $\mathrm{P} 1(\mathrm{RCD}=0.264, \mathrm{H}=0.170)$ and $\mathrm{P} 2(\mathrm{RCD}=0.087, \mathrm{H}=0.050)$. The predominance of apomictic individuals in higher trait size classes suggests better performance; however, apomixis underestimates the heritability analysis due to the fact that identical genomes reduce covariance for the traits (Table 1). The difference in the frequency between apomictic and non-apomictic is more variable in the lower size classes (Figure 1). Polyembryony, in which a species produces a large number of embryos and increases the concentration of individuals in the first growth classes or young ages, also influences heritability. Emerging species often have an irregular structure due to infrequent recruitment events, asynchronous flowering, and dependence on clearings for growth (KILLEN et al., 1998). The best performing apomictic genotypes may be potential candidates for seed sources to produce uniform progeny and build up large populations with genetically similar individuals. It is also a genetic fixation strategy, potentially enabling the indefinite multiplication of heterotic genetic combinations (BERTHAUD, 2001).

Heritability is environmentally specific for populations and can be affected by genetic and environmental variation and their interaction. As such, heritability may change in the same population with plant growth or may be different among populations, as observed between P1 and P2. The lower heritability for RCD and $\mathrm{H}$ in P2 than P1 is likely due to the fact that P2 presents a high rate of inbreeding and a lower number of juveniles than P1. All these factors occurring in natural populations influence genetic variation and consequently heritability over time and across subpopulations of the species in the studied plots.

Understanding levels of growth trait heritability in natural populations allows for the prediction of genetic effects of silvicultural practices including the management of natural regeneration and seed collection (KREMER, 1992). Our results show that the environmental effects are more pronounced than the genetic effects for controlling RCD and $\mathrm{H}$ in A. polyneuron. This means that there is limited potential for altering the mean trait values of the plots through natural or artificial selection, especially in P2 where there is a high level of inbreeding and a lower proportion of apomicts. Apomixis favors selection of individuals with better performance through the establishment of individuals highly adapted to local conditions, and immediate fixation of superior genotypes, creating identical plants 
independent of the level of heterozygosity (KOLTUNOW et al., 1995). Thus, the possibility of selecting superior genotypes with desirable traits increases and the selection of vigorous individuals is possible through analysis of juveniles with better genotype performance.

\section{CONCLUSIONS}

Aspidosperma polyneuron produces seeds by sexual reproduction and apomixis, but the youngest juveniles originate mainly from sexual reproduction. Apomictic individuals are predominant in the higher classes for the studied growth traits due to better performance of apomictic trees.

Related juvenile individuals are generally full-sibs.

Heritability is variable across plots and traits, with higher levels in plot 1 and for root collar diameter; artificial selection at the juvenile stage can change the population mean for these traits.

Estimates of heritability increase when apomictic individuals are excluded from the analysis.

\section{REFERENCES}

ARAUJO, D.; SEBBENN, A. M.; ZANATTO, A. C. S.; ZANATA, M.; MORAES, E.; MORAES, M. L. T.; FREITAS, M. L. M. Variação genética para caracteres silviculturais em progênies de polinização aberta de Astronium graveolens Jacq. (Anacardiaceae). Cerne, Lavras, v. 20, p. 61-68, 2014.

ASHLEY, M. V.; DOW, B. D. The use of microsatellite analysis in population biology: background, methods and potential applications. In: Schierwater BSB, Wagner GP, Desalle R (eds). Molecular Ecology and Evolution: Approaches and Applications. Birkhauser Verlag. 1994, p. 185-201.

AYRES, M.; AYRES, J. R. M.; AYRES, D. L.; SANTOS, A. S. BioEstat. Versão 5.0, Belém: Sociedade Civil Mamirauá,Brasil, 2007.

BELTRAME, R.; BISOGNIN, D. A.; MATTOS, B. D.; CARGNELUTTI FILHO, A.; HASELEIN, C. R.; GATTO, D. A.; SANTOS, A. S. Desempenho silvicultural e seleção precoce de clones de híbridos de eucalipto. Pesquisa Agropecuária Brasileira, Brasília, v. 47, n. 6, p. 791-796, 2012.

BERTHAUD, J. Apomixis and the management of genetic diversity. In: Savidan Y, Carman JG, Dresselhaus T (eds). The flowering of apomixis: from mechanisms to genetic engineering. El Batan: CIMMYT. 2001, p. 8-23.

BESSEGA, C.; SAIDMAN, B. O.; DARQUIER, M. R.; EWENS, M.; FELKER, P.; VILARDI, J. C. Accuracy of dominant markers for estimation of relatedness and heritability in an experimental stand of Prosopis alba (Leguminosae). Tree Genetics \& Genomes, Berlin, v. 7, n. 1, p. 103-115, 2011.

CARVALHO, P. E. R. Espécies arbóreas brasileiras. Brasília: Embrapa Informação Tecnológica / Embrapa Florestas, 2003, 1039 p.

CHAVES, C. L.; SEBBENN, A. M.; BARANOSKI, A.; GOEZ, B. D.; GAINO, A. P. C.; RUAS, C. F.; RUAS, E.; RUAS, P. M. Gene dispersal via seeds and pollen and their effects on genetic structure in the facultative-apomictic Neotropical tree species Aspidosperma polyneuron. Silvae Genetica, Frankfurt, v. 65, p. 1-12, 2017.

CHINELATO, F. C. S.; MORAES, C. B.; CARIGNATO, A.; TAMBARUSSI, E. V.; ZIMBACK, L.; PALOMINO, E. C.; MORI, E. S. Genetic variability in guapuruvu Schizolobium parahyba progênies. Scientia Agropecuaria, Trujillo, v. 5, p. 71-76, 2014.

CORNELIUS, J. Heritabilities and additive genetic coefficients of variation in forest trees. Canadian Journal of Forest Research, Ottawa, v. 24, p. 372-379, 1994.

COUTINHO, R. T.; BESPALHOK FILHO, J. C.; FRITSCHE NETO, R.; FRIZZO, C. Viabilidade da seleção precoce de Pinus taeda L. em diâmetro a altura do peito em programa de melhoramento genético. Scientia Forestalis, Piracicaba, n. 113, v. 45, p. 203-219, 2017.

DEMESURE, B.; GUERROUE, B. L.; LUCCHI. G.; PART, D.; PETIT, R. J. Genetic variability of a scattered temperate forest tree: Sorbus torminalis. L. Annals of Forest Science, Frankfurt, v. 57, p. 63-71, 2000.

DOYLE, J. J.; DOYLE, J. L. Isolation of plant DNA from fresh tissue. Focus, Rockville, v. 12, p. 13-15, 1990.

Sci. For., Piracicaba, v. 47, n. 122, p. 286-293, jun. 2019

DOI: doi.org/10.18671/scifor.v47n122.11 
Chaves et al. - Heritability of growth traits in a natural population of the

facultative apomictic tree Aspidosperma polyneuron

HARDY, O.; VEKEMANS, X. SPAGEDI: a versatile computer program to analyze spatial genetic structure at the individual or population levels. Molecular Ecology Notes, Oxford, v. 2, p. 618-620, 2002.

KALINOWSKI, S. T.; TAPER, M. L.; MARSHALL, T. C. Revising how the computer program CERVUS accommodates genotyping error increases success in paternity assignment. Molecular Ecology, Oxford, v. 16, p. 1099-1106, 2007.

KILLEN, T. J.; JARDIM, A.; MAMANI, F.; ROJAS, N. Diversity, composition and structure of a tropical semideciduous forest in the Chaquitanía region of Santa Cruz, Bolivia. Journal of Tropical Ecology, Cambridge, v. 14, p. $803-827,1998$.

KOLTUNOW, A. M.; BICKNELL, R. A.; CHAUDHURY, A. M. Apomixis: molecular strategies for the generation of genetically identical seeds without fertilization. Plant Physiology, Rockville, v. 108, p. 1345-1352, 1995.

KREMER, A. Predictions of age-age correlations of total height based on serial correlations between height increments in Maritime pine (Pinus pinaster AIT.). Theoretical and Applied Genetics, Berlin, v. 85, p. 152-158, 1992.

KUBOTA, T. Y. K.; SILVA, E. C. B.; MORAES, M. L. T.; TARAZI, R.; SEBBENN, A. M. Herdabilidade em caracteres de crescimento de populações fragmentadas da espécie arbórea Copaifera langsdorffii (Fabaceae). Scientia Forestalis, Piracicaba, v. 43, n. 105, p. 235-242, 2015.

LOISELLE, B. A.; SORK, V. L.; NASON, J.; GRAHAM, C. Spatial genetic structure of a tropical understory shrub, Psychotria officinalis (Rubiaceae). American Journal of Botany, New York, v. 82, p. 1420-1425, 1995.

MASSARO, R. A. M.; BONINE, C. A. V.; SCARPINATI, E. A.; PAULA, R. C. Viabilidade da aplicação da seleção precoce em testes clonais d Eucalyptus spp. Ciência Florestal, Santa Maria, v. 20, p. 597-609, 2010.

MORAES, C. B.; BRIZOLLA, T. F.; TEIXEIRA, L. G.; ZIMBACK, L; TAMBARUSSI, E. V.; CHAVES, R.; MORAES, M. L. T.; MORI, E. S. Estimativas dos parâmetros genéticos para seleção de arvores de Eucalyptus. Scientia Forestalis, Piracicaba, v. 42, n. 104, p. 623-629, 2014.

MOUSSEAU, T. A.; RITLAND, K.; HEATH, D. D. A novel method for estimating heritability using molecular markers. Heredity, London, v. 80, p. 218-224, 1998.

NAMKOONG, G. Introduction to quantitative genetics in forestry. Forest Service Technical Bulletin, Washington, n. 1588, 1- 342 p, 1979.

PAGLIARINI, M. K.; KONRAD, E. C. G.; SILVA, F. C.; SAMPAIO, M.; MOREIRA, J. P.; SATO, A. S.; MACHADO, J. A. R.; FREITAS, M. L. M.; AGUIAR, A. V.; MORAES, M. L. T.; SEBBENN, A. M. Variação genética em caracteres de crescimento em progênies de Dipteryx alata Vog. Scientia Forestalis, Piracicaba, v. 44, n. 112, p. 925-935, 2016.

PUPIN, S.; SANTOS, A. V. A.; ZARUMA, D. U. G.; MIRANDA, A. C.; SILVA, P. H. M.; SEBBENN, A. M.; MORAES, M. L. T.; MARINO, C. L. Produtividade, estabilidade e adaptabilidade em progênies de polinização aberta de Eucalyptus urophylla S.T. Blake. Scientia Forestalis, Piracicaba, v. 43, n. 105, p. 127-134, 2015.

RAMOS, R. F.; MONTEIRO, M.; ZUCCHI, M. I.; PINHEIRO, J. B.; MARTINEZ, C. A.; MESTRINER, M. A.; ALZETEMARIN, A. L. Microsatellite markers for Aspidosperma polyneuron (Apocynaceae), an endangered tropical tree species. American Journal of Botany, New York, v. 98, p. 300-302, 2011.

RESENDE, M. D. V. Genética biométrica e estatística no melhoramento de plantas perenes. Brasília: Embrapa Informação Tecnológica, 2002, 975 p.

RIBAS, L. L. F.; GUERRA, M. P; KULCHETSCKI, L.; ZANETTE, F. Micropropagation of Aspidosperma polyneuron Müll. Arg. From in vitro germinated seedlings. Ciência Florestal, Santa Maria, v. 27, p. 391-402, 2017.

RITLAND, K. A marker-based method for inferences about quantitative inheritance in natural populations. Evolution, Lancaster, v. 50, p. 1062-1073, 1996.

SEBBENN, A. M.; KAGEYAMA, P. Y.; DIO JUNIOR, O. J.; SIQUEIRA, A. C. F. M. Variação genética entre e dentro de populações de amendoim - Pterogyne nitens. Scientia Forestalis, Piracicaba, n. 56, p. 29-40, 1999a. 
SEBBENN, A. M.; SIQUEIRA, A. C. F. M.; VENCOVSKY, R.; MACHADO, J. A. R.; MACHADO, J. A. R. Interação genótipo x ambiente na conservaçao ex situ de Peltophorum dubium (Spreng) Taub. em duas regiões do Estado de São Paulo. Revista do Instituto Florestal, São Paulo, v. 11, n. 1, p. 65-78, 1999b.

SEBBENN, A. M.; SIQUEIRA, A. C. F. M.; VENCOVSKY, R.; MACHADO, J. A. R.; MACHADO, J. A. R.; KAGEYAMA, P. Y.; VANCOVSKY, R. Parâmetros genéticos na conservação de Cabreúva - Myroxylon peruiferum L. F. Allemão. Scientia Forestalis, Piracicaba, n. 53, p. 31-38, 1998.

SILVA, E. C. B.; KUBOTA, T. Y. K.; MORAES, M. L. T.; BITTENCOURT, J. V. M.; SEBBENN, A. M. Coeficiente de herdabilidade e de parentesco em um fragmento florestal de Araucaria angustifolia (Bertol.) Kuntze utilizando marcadores genéticos. Scientia Forestalis, Piracicaba, v. 43, p. 147-153, $2015 a$.

SILVA, P. H. M.; SHEPHERDS, M.; GRATTAPAGLIA, D.; SEBBENN, A. M. Use of genetic markers to build a new generation of Eucalyptus pilularis breeding population. Silvae Genetica, Frankfurt, v. 64, p. 170-181, 2015b.

TAMBARUSSI, E. V.; BOSHIER, D.; VENCOVSKY, R.; FREITAS, M. L. M.; SEBBENN, A. M. Inbreeding depression from selfing and mating between relatives in the Neotropical tree Cariniana legalis Mart. Kuntze. Conservation Genetics, New York, v. 18, p. 225-234, 2017.

TOREZAN, J. M. D.; SOUZA, R. F.; RUAS, P. M.; RUAS, C. F.; CAMARGO, E. H.; VANZELA, A. L. L. Genetic 721 variability of pre and post-fragmentation cohorts of Aspidosperma polyneuron Muell. Arg. (Apocynaceae). Brazilian Achieves of Biology and Technology, Curitiba, v. 48, p. 171-180, 2005.

ZARUMA, D. U. G.; CANUTO, D. S. O.; PUPIN, S.; CAMBUIM, J.; SILVA, A. M.; MORI, E. S.; SEBBENN, A. M.; MORAES, M. L. T. Variabilidade genética em procedências e progênies de Dipterys alata Vogel, para fins de conservação genética e produção de sementes. Scientia Forestalis, Piracicaba, v. 43, n.105, p. 30-45, 2015.

Received: 03/15/2018

Accepted: 09/25/2019 